\title{
Social Exchange Relationship, Economic Exchange Relationship, In-role Behavior: The Mediating Effects of Job Satisfaction
}

\author{
Yanhan $\mathrm{Zhu}^{1}$ \\ ${ }^{1}$ School of Political Science and Public Management, Southwest University, Chongqing, China \\ Correspondence: Yanhan Zhu, School of Political Science and Public Management, Southwest University, \\ Chongqing 400715, China. E-mail: littleyan@yahoo.cn
}

Received: January 18, $2012 \quad$ Accepted: March 25, $2012 \quad$ Published: July 1, 2012

doi:10.5539/ass.v8n8p194

URL: http://dx.doi.org/10.5539/ass.v8n8p194

The research is sponsored by Humanity and Social Science Youth funds of Ministry of Education "Study on the Effects of Exchange Relationship Perception on Individual Behavior"(12YJC630329), "the Fundamental Research Funds for the Central Universities(SWU1209373)" and "Social Science Doctor Fund Program of Southwest University"(SWU11333).

\begin{abstract}
The relationship between employees and their organizations has often been described as an exchange relationship. Based on the individual perception and "S-O-R" mode, this paper constructed a model that manifests the relationship between social exchange relationship, economic exchange relationship, and in-role behaviors, and then tested the mediating effects of job satisfaction. From the empirical results, the mediating effect of job satisfaction was very robust.
\end{abstract}

Keywords: social exchange relationship, economic exchange relationship, job satisfaction, in-role behavior

\section{Introduction}

The relationship between employees and their organizations has often been described as an exchange relationship (Mowday, Porter, \& Steers, 1982). So far, most studies of perceived exchange relationships have examined the employee's and the employer's half of the exchange separately (for example, POS and affective commitment in the commitment literature, and employee obligations and employer obligations in the psychological contracts literature). These literatures have focused on what is exchanged between employee and employer (for example, job security for loyalty in the psychological contracts literature; employer commitment for employee commitment), which has proved quite meaningful. However, other authors have suggested that understanding the impact of the exchange relationship itself may also be important. Tsui, Pearce, Porter, and Tripoli (1997) examined the exchange relationship from the employer's perspective, focusing on inducements offered and contributions expected of employees. Using inducements and contributions, they created four categories of employment relationships, two balanced and two unbalanced. Studies on employee-organization exchange generally take the view that employees treat the organization with human-like characteristics (Levinson, 1965) and that an individual employee and the organization can enter into an exchange relationship. A general idea of relationship is that exchange is the foundation of human's behaviors and social relationship, namely, the purpose of the employee is get the return from their organizations, the nature is "reciprocity". Without exception, all the exchange relationships have the following four concepts; they are actors, resources, structures, and processes. The participants of exchange be called as "Actors", the actor either be an individual or a group. When one party has the property that is very valuable for another party, the property becomes the resources. The resources either a tangible or intangible materials, such as money, service or something like that. The actor attempt to get more valuable resources which be controlled by others. While those exchange relationships exist in an interdependent structure. Shore et al said when the employee get the perception of social and economic exchange relationships, they would consider two parts, the first one was the organization's behavior, and the other is their response to organizational behavior. Shore et al emphasized the quality of exchange relationship. 


\section{Theoretical Background and Hypotheses}

\subsection{Social Exchange Relationship}

Social Exchange Relationship tends to be long term in nature. It involves the exchange of socio-emotional benefits with open ended obligations. The central norm underlying social exchange is reciprocity (Gouldner, 1960). Social Exchange literatures focus on reciprocal interdependence. It emphasizes on contingent interpersonal transactions, whereby an action by on party leads to a response by another. In this tradition, a reciprocal exchange is understood as one that does not include explicit bargaining. Classical exchange theories typically excluded bargaining and negotiation from the scope of their theories. Homans observed that explicit bargaining is rarely part of enduring relationships. Blau (1964) hat absence of negotiation is what distinguishes social from economic exchange. It is important for one party to trust the recipient to discharge his/her obligation.

\subsection{Economic Exchange Relationship}

Economic exchange is rather short-term and involves the exchange of concrete or economic resources in a quid pro quo fashion. The nature of obligations s specified in an explicit contract. In Economic Exchange, the respective obligations are specified, the parties are confident that each party will fulfill his/her obligations, a verbally negotiated arrangement, or a formal contract, which also dictates the duration of the relationship. In brief, the Economic Exchange reflects the exchange of tangible resources over a finite period or a discrete transition. The fulfillment of an Economic Exchange is vital to the continuation of the Employee-Organization Relationship.

\subsection{Job Satisfaction}

Job Satisfaction perhaps the most central and enduring construct in individual-level organizational research. Job satisfaction, although defined in many ways, has often been thought of as an emotional state resulting from the evaluation or appraisal of one's job experiences (Locke, 1976), or as a psychological state simultaneously represented by cognitive and affective indicators (Brief \& Weiss, 2002; cf. Schleicher, Watt, \& Greguras, 2004). Job satisfaction has been defined as a pleasurable emotional state resulting from the appraisal of one's job; an affective reaction to one's job; and an attitude towards one's job. Weiss (2002) has argued that job satisfaction is an attitude but points out that researchers should clearly distinguish the objects of cognitive evaluation which are affect (emotion), beliefs and behaviors.

\subsection{In-role Behavior}

In-role behavior we refer to the observance of corporate allocation decisions in accordance with formally prescribed roles. Core or IRB were initially described by Katz and Kahn (1978) as those behaviors that are prescribed and defined as being part of one's job, and are recognized by the organization's formal reward systems. Williams and Anderson (1991) defined IRB by behaviors such as working a full 8-h day or completing all required assignments. Performance criteria to measure in-role performance are often broken down into four basic categories: ratings, quality measures, quantity measures, and file data, such as records concerning safety, absences, or tardiness.

From the above, our study proposes the following theoretical framework (Figure 1) and hypotheses.

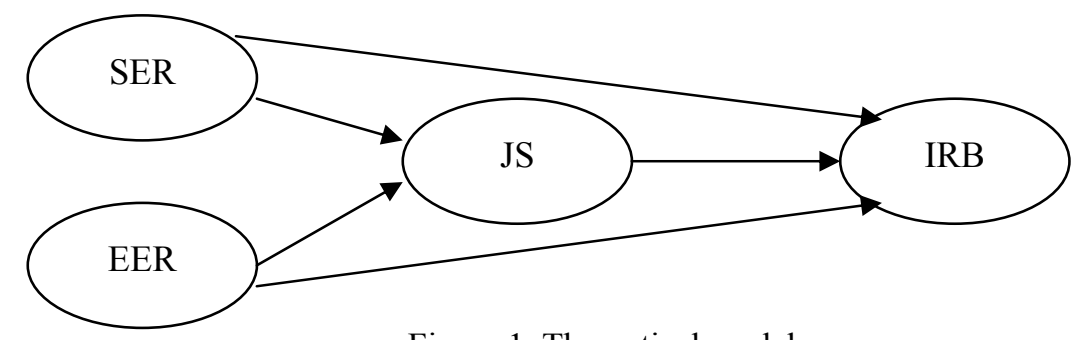

Figure 1. Theoretical model

Hypothesis 1: The employee's perceived Social Exchange relationship has the significant relationship with the employee's In-role behavior.

Hypothesis 2: The employee's perceived Economic Exchange relationship has the significant relationship with the employee's In-role behavior.

Hypothesis 3: Job Satisfaction will mediate the positive relationship between Social Exchange Relationship and the employee's In-role behavior. 
Hypothesis 4: Job Satisfaction will mediate the positive relationship between Economic Exchange Relationship and the employee's In-role behavior.

\section{Method}

\subsection{Sample and Procedures}

We collected the data from the different types of enterprises in China (foreign-invested enterprises, state-owned enterprise, private enterprises and so on). Of the 232 questionnaires distributed, 209 completed questionnaires. Within the sample, 52.2 percent were male, 52.8 percent were married, and 96.3 percent were below the age of 40 .

\subsection{Measures}

We adopted all the measurement items in the questionnaire from established scales developed in the West with sufficient validity and reliability. Two PhD Candidates (both of them got the Commercial English bachelor degree) in China conducted a back translation where the measurement scales used in the present study were translated into Chinese and then translated back into English. All study variables were measured on a six-point Likert-type scale ( $1=$ 'strongly disagree' and $6=$ 'strongly agree') to avoid the central tendency bias (choosing the midpoint of the scale).

Social Exchange Relationship. This study used the eight-item scale developed by Shore et al. (2006) to measure the respondents' perceptions of socio-emotional exchange with the organization. The Cronbach's alpha was 0.89 for this scale. As for the validity, the AVE was 0.52 .

Economic Exchange Relationship. This study used the eight-item scale developed by Shore et al.(2006) to measure the respondents' perceptions of Economic Exchange with the organization. This scale's Cronbach's alpha was 0.77 . As for the validity, the AVE was 0.51 .

In-role Behavior. This study used the eight-item scale developed by Larry J. Williams \& Stella E. Anderson (2001) to measure the respondents' in-role behavior. This scale's Cronbach's alpha was 0.898. As for the validity, the AVE was 0.62 .

Job Satisfaction. This study measured job satisfaction using five items from the Timothy A. Judge et al. The five items are, "Most days I am enthusiastic about my work," "I feel fairly satisfied with my present job," "I find real enjoyment in my work," "Each day at work seems like it will never end," and "I consider my job rather unpleasant." The last two items are reverse scored. The Cronbach's alpha was 0.82 for this scale. As for the validity, the AVE was 0.56 .

\subsection{Analyses and Results}

This study employed structural equation modeling (SEM) to test the hypotheses, using AMOS 17.0. We first estimated the fit of the measurement model using confirmatory factor analysis (CFA) and then evaluated the fit of the structural models. Overall model fit was examined by various fit indices including root mean square error of approximation (RMSEA), incremental fit index (IFI), and comparative fit index (CFI) and so on (Table 1).

Table 1. Main effect

\begin{tabular}{|c|c|c|c|c|}
\hline Hypotheses & loading & Standard loading & T (Sig.) & \\
\hline H1: SE---IRB & 0.147 & 0.17 & $3.363(* * *)$ & \\
\hline H2: EE---IRB & -0.093 & -0.106 & $-2.163(*)$ & \\
\hline $\begin{array}{l}\mathrm{FI}: \quad \chi^{2} / d f=2.2 ; \\
\text { PNFI=0.75; PGFI }=0.6\end{array}$ & $\begin{array}{l}\text { RMSEA=0.046; } \\
89\end{array}$ & $\mathrm{RMR}=0.041 ; \quad \mathrm{GFI}=0$ & $5 ; \mathrm{IFI}=0.958$ & $\mathrm{RFI}=0.91$; \\
\hline
\end{tabular}

$* * * \mathrm{p}<0.001 ; * \mathrm{p}<0.1$

After the analysis, this study got the above results, namely, the main test was supported. 


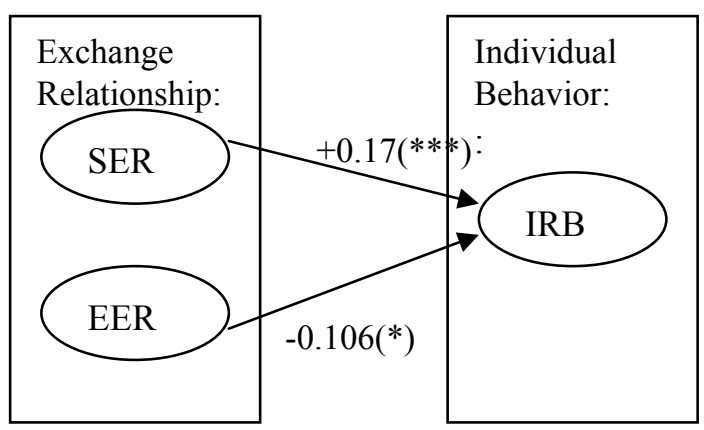

Figure 2. Results for main test

Hypothesis 1: The employee's perceived Social Exchange relationship has the significant relationship with the employee's In-role behavior. (Supported)

Hypothesis 2: The employee's perceived Economic Exchange relationship has the significant relationship with the employee's In-role behavior. (Supported)

To test the mediation effect, we examined the four conditions suggested by Baron and Kenny (1986). First, the independent variable is significantly related to the outcome variable. Second, the independent variable is significantly related to the mediator. Third, the mediator is significantly related to the outcome variable. Finally, after controlling for the mediator, the direct effect of the independent variable on the outcome variable becomes weaker or non-significant. To make sure that our mediation hypotheses fulfilled the above conditions, this study estimated three nested structural models (Kelloway, 1998). We then evaluated the model fit of these nested models, and we employed difference tests to determine the best model. The parameter estimates of the accepted model were then used to test the hypotheses (Table 2).

Table 2. Mediating effect

\begin{tabular}{|c|c|c|c|c|}
\hline \multicolumn{5}{|l|}{ Model 1} \\
\hline Hypotheses & loading & C.R(t) & S.E & Sig. \\
\hline EER ---- JS & (a) -0.524 & -8.711 & 0.059 & $* * *$ \\
\hline JB ----- IRB & $\left(b_{1}\right) 0.355$ & 5.787 & 0.073 & $* * *$ \\
\hline EER ----- IRB & $\left(c_{1}\right) 0.114$ & 1.897 & 0.07 & 0.058 \\
\hline \multicolumn{5}{|c|}{$\chi^{2} / d f=2.531 ; \mathrm{RMSEA}=0.049 ; \mathrm{RMR}=0.041 ; \mathrm{GFI}=0.95$} \\
\hline \multicolumn{5}{|c|}{$\mathrm{IFI}=0.961 ; \mathrm{RFI}=0.922 ; \mathrm{PNFI}=0.765 ; \mathrm{PGFI}=0.686$} \\
\hline \multicolumn{5}{|c|}{ Model 2} \\
\hline Hypotheses & loading & C.R(t) & S.E & Sig. \\
\hline SER ----- JS & (a) 0.593 & 10.023 & 0.059 & $* * *$ \\
\hline JS ----- IRB & $\left(b_{1}\right)_{0.27}$ & 4.236 & 0.072 & $* * *$ \\
\hline SER ----- IRB & $\left(c_{1}\right) 0.018$ & 0.291 & 0.068 & 0.771 \\
\hline \multicolumn{5}{|c|}{$\chi^{2} / d f=2.440 ; \mathrm{RMSEA}=0.05 ; \mathrm{RMR}=0.044 ; \mathrm{GFI}=0.947$} \\
\hline \multicolumn{5}{|c|}{$\mathrm{IFI}=0.961 ; \mathrm{RFI}=0.921 ; \mathrm{PNFI}=0.764 ; \mathrm{PGFI}=0.687$} \\
\hline
\end{tabular}

Hypothesis 3: Job Satisfaction will mediate the positive relationship between Social Exchange Relationship and the employee's In-role behavior. (Supported)

Hypothesis 4: Job Satisfaction will mediate the positive relationship between Economic Exchange Relationship and the employee's In-role behavior. (Supported) 


\section{Discussion and Management Implication}

From the above, it is clearly that hypotheses all be supported. Specifically, the employee's perceived Social Exchange Relationship positively relate to the employee's In-role behavior. The standard coefficient is 0.17 and significant when $\mathrm{p}$ value is less than 0.001. As for the relationship between Economic Exchange relationship and In-role behavior, this study get a conclusion opposed to the common sense, namely, the employee's perceived Economic Exchange relationship negatively relate to the employee's In-role behavior. The standard coefficient is 0.106 and significant when $p$ value is less than 0.1 . Job Satisfaction mediates the positive relationship between (a) Social Exchange Relationship and the employee's In-role behavior and (b) Economic Exchange Relationship and the employee's In-role behavior.

This conclusion opens a new window for Human Resource Management Practice. Build supportive human resource management practice, establish and maintain the social exchange relationship with employees, and enhance employees' social exchange relationship perception. Construct cooperative labor relations between employees and enterprises. Build the people-oriented enterprise culture and improve employees' affective job satisfaction. Affective job satisfaction has a tempting and driving effect on employees spontaneously conducting pro-business behaviors. Differing from cognitive job satisfaction, the construction of affective job satisfaction focuses on the enterprise's general emotional input in employees. To build the people- oriented enterprise culture is an effective way of improving employees' affective job satisfaction.

\section{References}

Allen, D. C., Shore, L. M., \& Griffeth, R. W. (2003). The role of perceived organizational support and supportive human resource practices in the turnover process. Journal of Management, 29, 99-118. http://dx.doi.org/10.1016/S0149-2063(02)00222-2

Alvin W. Gouldner. (1960). The norm of reciprocity: a preliminary statement. American Sociological Review, 25, 161-178.

Ann, E. S., Tsui, Jone, L., Pearce, Lyman, W. Porter, \& Angela M. Tripoli. (1997). Alternative approaches to the employee-organization relationship: does investment in employees pay off? Academy of Management Journal, 40, 108.

Babin, B. J., \& Boles, J. S. (2002). The effects of perceived co-worker involvement and supervisor support on the service provider role stress, performance and job satisfaction. Journal of Retailing, 72, 57-75. http://dx.doi.org/10.1016/S0022-4359(96)90005-6

Calder, Bobby, J., \& Alice, M. Tybout. (1999). A Vision of Theory, Research, and the Future of Business Schools, Journal of the Academy of Marketing Science, 27, 359-366. http://dx.doi.org/10.1177/0092070399273006

Carmeli, A., \& Freund, A. (2004). Work commitment, Job satisfaction, and Job performance: An empirical investigation. International Journal of Organization Theory and Behavior, 7(3), 289-309.

Chen, Z. X., Aryee, S., \& Lee, C. (2005). Test of a mediation model of perceived organizational support. Journal of Vocational Behavior, (66), 457-470. http://dx.doi.org/10.1016/j.jvb.2004.01.001

Colquitt, J. (2008). From the Editors, Publishing Laboratory Research in AMJ: a Question of When, Not If. Academy of Management Journal, 51, 616-620. http://dx.doi.org/10.5465/AMJ.2008.33664717

Colquitt, J. A., \& Zapata-Phelan, C. P. (2007). Trends on theory building and theory testing: A five-decade study of the Academy of Management Journal. Academy of Management Journal, 50, 1281-1303. http://dx.doi.org/10.5465/AMJ.2007.28165855

Conway, J. M., \& Lance, C. E. (2010). What reviewers should expect from authors regarding common method bias in organizational research. Journal of Business \& Psychology, 25, 325-334. http://dx.doi.org/10.1007/s10869-010-9181-6

Coyle-Shapiro, J. A. M., \& Neuman, J. H. (2004). The Psychological Contract and Individual Differences: the Role of Exchange and Creditor Ideologies. Journal of Vocational Behavior, 64, 150-164. http://dx.doi.org/10.1016/S0001-8791(03)00031-9

Cropanzano, R., \& Baron, R. A. (1991). Injustice and Organizational Conflict: the Moderating Effect of Power Restoration. International Journal of Conflict Management, 2, 5-26. http://dx.doi.org/10.1108/eb022691

Cycyota, C. S., \& Harrison, D. A. (2006). What (not) to expect when surveying executives. Organizational Research Methods, 9, 133-160. http://dx.doi.org/10.1177/1094428105280770 
Duanxu Wang, Anne S. Tsui, Yichi Zhang, \& Li Ma. (2003). Employment relationships and firm performance: evidence from an emerging economy. Journal of Organizational Behavior, 24, 511-535. http://dx.doi.org/10.1002/job.213

Francis J. Flynn. (2005). Identity orientations and forms of social exchange in organizations. Academy of Management Review, 30, 737-750. http://dx.doi.org/10.5465/AMR.2005.18378875

Glick, W.H., Miller, C.C., \& Cardinal, L.B. (2007). Making a life in the field of organizational science. Journal of Organizational Behavior, 28, 817-835. http://dx.doi.org/10.1002/job.455

Harry Levinson. (1965). Reciprocation: The relationship between man and organization. Administrative Science Quarterly, 9, 370-390.

Jacqueline A. M. Coyle-Shapiro, \& Lynn M. Shore. (2007). The employee-organization relationship: where do we go from here?. Human Resource Management Review, 17, 166-179. http://dx.doi.org/10.1016/j.hrmr.2007.03.008

Jacqueline A. M. Coyle-Shapiro, \& Neil Conway. (2004). The employment relationship through the lens of social exchange. The Employment Relationship: Examining Psychological and Contextual Perspectives. Oxford University.

Le, H., Schmidt, F. L., Harter, J. K., \& Lawler, K. J. (2010). The problem of empirical redundancy of constructs in organizational research: an empirical investigation. Organizational Behavior and Human Decision.

Lunderen, S. M., Nordholm, L., \& Segesten, K. (2005). Job satisfaction in relation to change to all RN staffing. Journal of Nurse Management, 13, 322-328. http://dx.doi.org/10.1111/j.1365-2934.2005.00565.x

Lynda Jiwen Song, Anne S. Tsui, \& Kenneth S. Law. (2009). Unpacking employee responses to organizational exchange mechanisms: the role of social and economic exchange perception?. Journal of Management, 35, 56-93. http://dx.doi.org/10.1177/0149206308321544

Mowday Richard T., Porter Lyman W., \& Steers Richard M. (1982). Employee-organization linkages: The psychology of commitment, absenteeism, and turnover. New York.

Shore, L. M., Tetrick, L. E., Lynch, P., \& Barksdale, K. (2006). Social and economic exchanges: construct development and validation. Journal of Applied Social Psychology, 36, 837-867. http://dx.doi.org/10.1111/j.0021-9029.2006.00046.x

Stephen J. Deery, \& Roderick D. Iverson. (2005). Labor-Management Cooperation: Antecedents and Impact on Organizational Performance. Industrial and Labor Relations Review, 58(4).

Wayne, Shore, \& Bommer, T. (2003). The role of fair treatment and rewards in perception of organizational support and leader member exchange. Journal of Applied Psychology, Washington, 87(3), 590. 